\title{
Sites of transgression: The suburbs and the city in Thomas Dekker's Shoemaker's Holiday
}

\author{
Paul J. C. M. Franssen \\ Utrecht University
}

\begin{abstract}
The early modern binary of the virtuous City of London versus the sinful suburbs clashes with an older binary pitting the countryside against the city. At the same time, the forces of urbanization along with early capitalism were undermining both binaries. This article traces how this is reflected in Thomas Dekker's The Shoemaker's Holiday. The play not only represents the City of London under Simon Eyre's rule as, potentially, possessing all the virtues of the pastoral, but also suggests that the surrounding countryside, in particular the village of Old Ford, was being corrupted by city values. Dekker's play, therefore, deconstructs simple dichotomies between country and city, showing how the two inevitably influence each other.
\end{abstract}

KEYWORDS: Thomas Dekker, The Shoemaker's Holiday, City Comedy, Countryside.

Jean Howard's fascinating study of City Comedy, or as she prefers to call it, London Comedy, is structured around a variety of real places within London, some specific (such as the Royal Exchange and the various Counters or debtors' prisons), others generic (such as bawdy houses and dancing academies). Howard associates these places within London with various discourses of gender, national identity, class, and the new money values. She regards these discourses as not primarily reflections of what really happened at these sites, but at least as much as constituting ways of thinking about such places, turning them into meaningful social spaces (2007:3, 32). Howard shows how the explosive growth of London into a world city undermined old certainties, often cast in the form of simple binaries,

$$
\text { E. ederi } 22 \text { (2012: 139-154) }
$$


between male/female, domestic/ foreign, aristocratic/common. For instance, foreign businessmen and French dancing masters could be construed as a threat to national identity, yet in a globalising world they also had attractive services to offer which one ignored at one's peril - indeed, which perhaps needed to be emulated by Londoners. Also, the received idea that the City itself was clean and virtuous, as were its women, and that prostitution had been banished to the City's outskirts, the liberties or suburbs, was undermined by the spread of prostitution to unmarked houses, often masquerading as respectable citizens' dwellings (2007:121f). Even the distinction between respectable women and others was not so clear anymore in a proto-capitalist society where everything was for sale (or so the discourse ran): where whores became respectable by marriage, whereas respectable women were sometimes exploited, sometimes themselves exploited their own charms, to sell consumer goods in the Exchange. The fluid lines between whore and matron, gentleman born and self-fashioned man (or woman) about town, between hopeless debtors and beaux who show their creditworthiness by overspending: all these suggest a deep-rooted anxiety about social changes in a world that was becoming increasingly complicated. We see then that, in city comedies, the binaries of London's selfrepresentation are deconstructed under pressure from rapid changes in society.

But how about that older binary, the contrast between the city and the surrounding countryside? Raymond Williams (1973) has traced this opposition, and its associations of simplicity versus sophistication, innocence versus vice, to its roots in classical Greek pastoral writers. One could even argue that it underlies biblical representations of cities like Babel and the Great Whore, Babylon. In the context of London and its rural environment, however, this simple dichotomy was complicated by the existence of London's suburbs, the liminal places outside the walled city, where theatres, bear-baiting arenas, places of execution, and bawdy houses were tolerated as a necessary evil. ${ }^{1}$ The City of London, so to speak, tried to export its vice and undesirable activities to just beyond its doorstep, putting out the garbage to keep its house clean. Insofar as London within the walls looked upon itself as a relatively orderly

\footnotetext{
${ }^{1}$ See e.g. Mullaney (1982:52-75 and passim); Twyning (1998:54-91 passim); Hayes (2000:58); and Howard (2007:121).
} 
place, an "integral and coherent whole," surrounded and occasionally threatened by a zone of licence and licentiousness in the Liberties outside the city walls (Mullaney 1982:54), this meant a partial inversion of the older City/Country stereotype: from a City point of view, some of the vices traditionally associated with cities were now typically located in a ring around its walls.

But where precisely does this suburb stop, and this innocence of the countryside begin? The village of Brentford or Brainford is a case in point: some 8 miles from London, it was a rural village, beyond the suburbs. Yet, as Charles Nicholl has argued, it was associated with vice. It was the place where, reputedly, Londoners went for a "dirty weekend" (2007:233). It may be for that reason that the three "Ho" plays all involve expeditions by citizens, including citizen's wives, away from the City centre, towards Brainford in the West, Cuckold's Haven in the East, and North to Ware, respectively, to give in to their lustful appetites there, away from the City where they are generally known. This is, in a sense, the reverse of our modern idea of the city as an anonymous place where one can be lost and unobserved in a crowd, so that social restrictions on behaviour are weakened: in Brainford, "you are out of eyes, out of ears: private rooms," as Linstock describes it when recommending it to his friends when choosing a venue to take their illicit lovers for a tryst. ${ }^{2}$ In her discussion of the three "Ho" plays, Howard seems to regard Brainford, and even Ware, some 22 miles north of London, as simply part of the suburbs (2007:123). Thus, at the intersection between London's self-image as a city surrounded by a ring of vice on the one hand, and the time-honoured contrast between countryside and city on the other, simple dichotomies fade away into indeterminacy; and the traditional pastoral idyll ${ }^{3}$ is tainted by contact with the city.

In this article, I propose to investigate the cultural signification of city and countryside in an early city comedy, Thomas Dekker's Shoemaker's Holiday (1599). This play is largely set in the City, where one of its plots traces the rise of humble shoemaker Simon Eyre to

\footnotetext{
${ }^{2}$ Westward Ho 2.2.327-328, quoted by Nicholl (2007:234). David Scott Kastan does see modern urban alienation in The Shoemaker's Holiday, however, where "Jane can actually be lost in the burgeoning urban density of London" (1987:329).

${ }^{3}$ By pastoral idyll I mean, in the words of Sukanta Chaudhuri, a "world of the imagination, invested with urban longing for an ideally simple life in nature" (1989:1).
} 
the position of Lord Mayor - which he promptly celebrates by a feast for all of London's apprentices. Another City plot tells the story of one of Eyre's journeymen shoemakers, Ralph, who is impressed for the wars in France. When he returns, he has lost one of his legs, and his young wife has disappeared; but Eyre generously gives him his old job back, and Ralph then manages to trace his wife, Jane, just in time to prevent her remarriage to a rich City gentleman, Hammon. Both these City plots celebrate the solidarity of all shoemakers, which makes London into a better place. The third plot, however, is partly set in the countryside: it is a love story, involving a young aristocrat, Lacy, and Rose, the daughter of the current Lord Mayor Simon Eyre's predecessor - Sir Roger Oatley. Sir Roger does not want his daughter to marry Lacy, nor does Lacy's uncle desire the match; but true love will find ways, so Lacy, who is due to leave for the French wars as a commander, stays behind in disguise as a Dutch shoemaker, Hans, to avoid being separated from Rose. Again, Eyre hires the pretended immigrant Hans, not knowing he is really Lacy in disguise, and is rewarded by Lacy presenting him with an opportunity to get rich. Eyre then stands up for the young couple when they elope, and obtains their pardon from the king. Significantly, some of the scenes involving Rose are set not in the City but in her father, Sir Roger's, house in the country, at a place called Old Ford.

It has long been recognised that Dekker's London, under the charismatic mayoralty of Simon Eyre, represents the pastoral ideal transferred to the city; ${ }^{4}$ but where does that leave the surrounding countryside, in particular the play's other setting, the village of Old Ford? Old Ford has long since been swallowed up by London, but in Dekker's time, it was a rural village some three-and-a half miles to the north east of London (Hayes 2000:59). It was not part of the disreputable London suburbs as such, but remained part of the countryside until it was swallowed up by the metropolis in the $19^{\text {th }}$ century (Maddocks 1933). Critics of the play, in so far as they comment on the representation of Old Ford, tend to regard it as a pastoral site. ${ }^{5}$ I will argue, however, that it is represented as tainted

\footnotetext{
${ }^{4}$ See e.g. Mortenson (1976:242-243).

5 Hayes, e.g., argues that Dekker's play merges a timeless pastoral discourse, embodied in Rose in her Old Ford setting, with a more satirical appraisal of contemporary London (2000:28). Although there is some overlap between my
} 
by city values, city people: that Old Ford is an outpost of the City masquerading as the countryside. It is therefore the mirror image of Simon Eyre's feast, which establishes country values within the City; and in sum, this exchange of values ends up blurring the differences between country and city altogether.

Admittedly, the play's early scenes do briefly evoke the traditional contrast between city and countryside, but quickly proceed to deconstruct it, partly by inverting it, partly by levelling out the differences: Old Ford is not a place of pastoral idylls and innocent virgins, nor is it a site of true hospitality. Simon Eyre, by contrast, shows that the best of the old-fashioned country values - its generosity and sense of belonging to a body politic - can be revived in a city environment. Thus, as in Jean Howard's argument, Dekker undermines certainties and deconstructs binaries in a play where nothing is quite what it seems: where a foreign shoemaker is really an aristocrat in disguise, and a real shoemaker comes to be the Lord Mayor who entertains the king.

Dekker's first two scenes do seem to evoke a vivid contrast between the play's settings. The first, long scene predominantly appeals to stereotypical negative ideas about the City, showing it as ambitious, involved with money values, and associating it with war. ${ }^{6}$ First, we are reminded of the cynicism and deviousness so often associated with the City. We see two older gentlemen, Sir Roger Oatley, the Lord Mayor, and Sir Hugh, the Earl of Lincoln, discussing the undesirable liaison between Oatley's daughter, Rose, and Sir Hugh's nephew, Lacy. Both have their own reasons for disapproving of this love affair. Sir Hugh objects to the girl's social standing, since Oatley, in spite of his title and position as Mayor of London, is really a nouveau riche - a former grocer, as we learn later (11.43). ${ }^{7}$ As Paul Seaver has explained, grocers may rank considerably higher than shoemakers, but they are still only citizens (1995:92). Sir Roger Oatley, on the other hand, does not want Lacy

argument and Hayes's, I disagree with her emphasis on the two main women characters, Rose and Margery, as the chief embodiments of the values of the idealised medieval city (consonant with pastoral values) and the sinful suburbs respectively. In my reading, the chief embodiments of conflicting values are Simon Eyre, the generous Lord Mayor, and his predecessor, the ambitious and miserly Sir Roger Oatley.

${ }^{6}$ On the latter association, see Williams (1973:17).

${ }^{7}$ Dekker (1990:56). All textual references are to this edition. 
for his son-in-law as he sees him as a good-for-nothing aristocratic spendthrift. The latter impression is confirmed by Lacy's uncle, who speaks of him as having been a "bankrupt" during his foreign travels; but the Earl is, characteristically, even more indignant about the young man's remedy of taking up the trade of a shoemaker in Wittenberg: "A goodly science for a gentleman|Of such descent!" (1.30-31). Class divisions and prejudices are obvious in their dialogue. What is more, though the two gentlemen politely agree that a marriage between the young lovers is to be avoided, they are far from honest about their real mutual feelings, as becomes clear in asides: Oatley calls Sir Hugh a subtle "fox" for hiding his real objections to Rose in deprecating remarks about his own nephew as a husband (1.38), whereas Sir Hugh calls Oatley a "churl" behind his back (1.78). One way they attempt to resolve the situation is by offering Lacy money, in effect a bribe, to go to the wars in France and forsake his love. The rest of the scene shows the preparation for these wars: we witness the conscription of newly-married Ralph, a shoemaker, against his own will and that of his bride and fellowshoemakers. This action is presided over by Lacy, who has secretly arranged for a friend to take his place as commander of the forces, yet hypocritically insists that Ralph cannot be let off. ${ }^{8}$ The shoemakers, too, attempt bribery (offering Lacy seven years' worth of boots, 1.135), but in vain.

In light of so much duplicity, hypocrisy, money values, class tensions, and the threat of war, all in a London setting, the opening of the second scene strikes a vivid contrast: we see Rose in the peaceful rural environment of Old Ford, making a garland for her lover, Lacy, and apostrophising herself as follows:

Here sit thou down upon this flow'ry bank, And make a garland for thy Lacy's head.

These pinks, these roses, and these violets, These blushing gilliflowers, these marigolds, The fair embroidery of his coronet, Carry not half such beauty in their cheeks As the sweet countenance of my Lacy doth. (2.1-7)

\footnotetext{
${ }^{8}$ Parr notes the "ironic social comment [...] apparent [...] when Lacy bribes Askew to cover for his absence from the French wars, and then pulls rank to remind Jane and Ralph of their obligations" (Dekker 1990:xiii).
} 
As Hayes suggests repeatedly, the imagery represents Rose as a shepherdess, framed in pastoral surroundings (2000:16, 30, 6of). Indeed, nymphs weaving garlands for their lovers are a pastoral cliché (Chaudhuri 1989:127, 129). However, unlike Hayes, I believe the pastoral idyll is severely qualified soon afterwards. First, we learn that the idyllic setting is not one of Rose's own choosing: in fact, Londoner Rose, the Lord Mayor's daughter, has been sent to her father's country dwelling in Old Ford to be out of harm's way, to keep her away from her lover, Lacy. She complains that, "robbed of [her] love," she is "imprisonèd" in these "walls" "as a thief" (2. 1012). In one production, at the Rose theatre in November 2008, that image was taken literally, as her "imprisonment was figured behind the metal fence that cordons off the historic Rose remains from public access" ${ }^{\prime 9}$ (Li 2009:147). Hayes suggests that Rose's being in an enclosed garden rather than an open field signifies her virginity (2000:30); but then again, this virginity is enforced by her father rather than being of Rose's own free choice. In most pastorals, nymphs can choose freely whether they will listen to their passionate shepherds - unless, of course, that shepherd or the nymph herself are really of noble blood, as is the case with The Winter's Tale. After all, the lower a person's rank, the freer they usually are to choose their own partner. ${ }^{10}$ That, of course, is the point here as well. In spite of initial appearances, Rose is not a shepherdess, nor even a princess in disguise as a shepherdess, a scenario which might fit into a pastoral make-believe context; she is a prosaic city heiress, whose fortune is large enough to be in need of protection, which is why her father has locked her safely away in the countryside. What may seem like an idyllic field is, on second glance, a prison.

Nor does the house at Old Ford prove to be the bulwark of safety and innocence that Rose's father thinks it is, when he congratulates himself on having sent her there, out of harm's way ( 1 . 41; 9. 104). Before long, her disguised lover Lacy sees her there, during her father's dinner party; the renewed acquaintance leads to their elopement and clandestine marriage in Savoy, one of the "sinful" suburbs (Hayes 2000:62-63), and therefore the nominal

\footnotetext{
${ }^{9}$ It would be interesting to study the contrast between the London setting and Old Ford in stage practice, but this issue is rarely mentioned in reviews of productions.

${ }^{10}$ As Paul Seaver also notes (1995:98), albeit in reference to Hammon rather than to Rose.
} 
antithesis of Old Ford - an antithesis that is therefore deconstructed. ${ }^{11}$ Oatley's tyranny has undermined the natural relationship between parents and children that supposedly obtains in a pastoral environment, and turned his daughter into a rebellious devious liar - albeit one who has our sympathy.

The dangers of transgression inherent in this seemingly idyllic place of Old Ford are adumbrated in the curious linked scenes 5 and 6, again set at Old Ford. First, two hunting gentlemen, Hammon and Warner, pass over the stage, chasing a stag near Old Ford; but a boy tells them the animal has leapt into "my Lord Mayor's pale" (5.12). The next scene shows Rose and her maidservant Sybil: the deer has indeed entered their garden, been caught by Sybil and other servants using a "flail" and a "prong" to bring it down, and slaughtered in the most prosaic way imaginable. In Sybil's words: "down he fell, and they [the male servants] upon him, and I upon them. By my troth, we had such sport! And in the end we ended him, his throat we cut, flayed him, unhorned him [...]" (6.6-9). The contrast with pastoral pity for suffering deer could hardly be more vivid. Rose, told about this after the event, decides to cover for her servants, but worries lest there might be trouble: "Hark, Hark, the hunters come. You're best take heed.|They'll have a saying to you for this deed" (6.11-12). When the hunters arrive, Rose feigns surprise:

It is not like the wild forest deer

Would come so near to places of resort.

You are deceived; he fled some other way. (6.24-26)

The gentlemen, however, are not really interested in the stag: their game is the girls, with Hammon pursuing Rose, in a passage of repartee turning on puns like dear/deer, hart/heart, and the inevitable joking about the stag's horns. In part, the dialogue runs as follows:

ROSE Why do you stay, and not pursue your game?

$[\ldots]$

HAMMON A deer more dear is found within this place.

ROSE But not the deer, sir, which you had in chase.

HAMMON I chased the deer; but this dear chaseth me. (6.29-33)

${ }^{11}$ Smith agrees that the Savoy was a "spot well-known for clandestine marriages" (2005:344). 
Meanwhile, Hammon's companion, Warner, tries to seduce the maid, Sybil. The scene ends inconclusively, with the women not won over. However, Rose's father, Sir Roger Oatley, arrives and approves of Hammon's interest in his daughter; as a rich but untitled gentleman, Hammon is his preferred choice over Lacy, the aristocratic spendthrift.

The scene has not been commented on very extensively by critics. Often, the nearness to nature of this outpost of London is noted, as a guarantor of the pastoral atmosphere; ${ }^{12}$ and the repartee is analysed as an example of Hammon's tired use of Petrarchan clichés, which shows his unsuitability as Rose's lover (Mortenson 1976:250). However, the scene can also be read as demystifying the seeming pastoral idyll. Rose asks Sybil on account of the catching of the deer, "Why, Sybil, wilt thou prove a forester?", and Sybil answers scornfully: "Upon some, no! Forester, go by" (6.1-2). The implicit suggestion is that both are really city girls, playing at being country folk - just like Hammon and Warner are city gentlemen playing at being landed aristocrats by hunting. ${ }^{13}$ What is more, when Rose denies the likelihood of deer coming so close to the built-up area, this is not so much a genuine description of an idyllic natural setting, rather, it is a lie covering up for her servants, who she knows have already cruelly dispatched the animal. As we have seen, Rose worries about the consequences of her servants' actions, possibly because thus stealing the gentlemen's booty might be construed as poaching, as deer hunting is an aristocratic prerogative. But just as the girls transgress the rules, so do the gentlemen hunters, whose breaking into the "pale" (5.12) of the Lord Mayor's household suggests their predatory attitude to wooing. The fact that the garden is metaphorically described as a "park" (6.35) again reminds one of poaching. This is definitely true of Warner, who woos Sybil in such a physical way that she needs to tell him to keep his "hands off, sir!" (6.47). Warner appears to be already married - since Hammon, himself unmarried, introduces him as his brother-in-law (6.50).

\footnotetext{
${ }^{12}$ Seaver sees Old Ford as a "leisured world of pastoral romance," in contrast to the harsher world of London (1995:97). Hayes sees the presence of deer so near the houses as a sign that Old Ford "has as yet only been partially domesticated: outside the City walls we may still find wilderness" (2000:61).

${ }^{13}$ On the latter point, see Manheim (1970:318-319), Smallwood and Wells (Dekker 1979:36), and Straznicky (1996:363).
} 
Hammon only has eyes for Rose. Although her father welcomes him as a prospective son-in-law, his chasing of Rose is a kind of poaching as well, as her heart belongs to Lacy. ${ }^{14}$ There is a neat symmetry here, as Sybil has just caught the deer that Hammon was hunting, while Hammon is now chasing the "dear" (Rose) that is really Lacy's quarry. Later, Hammon really turns out to be a poacher when he nearly succeeds in stealing Jane, a married woman, by pretending that her husband Ralph was killed in the French wars. Tellingly, in the scene where he attempts to win Jane over, he repeatedly speaks of wooing her in terms of buying her wares or her time (12.24-33); and later he offers Ralph twenty pounds for his wife (18.79). This deer hunter is not the pastoral figure he may appear at first, but a man of the city, who believes money can buy everything. ${ }^{15}$

The contemporary overtones of the deer hunt as transgressive can be demonstrated from the prime source of the puns and conceits introduced by Hammon and Rose: Petrarch's "Una Candida Cerva," famously translated by Sir Thomas Wyatt as "Whoso list to hunt," and ending with the forbidding inscription on the deer's collar, "touch me not, for Caesar's I am." For Petrarch, the vision of a deer had stood for Laura after her death, who, like Christ, belongs to the Kingdom of God and is therefore not to be touched; Wyatt apparently recast this as a bitter comment on Anne Boleyn, who belonged to the secular ruler, Henry VIII, and was therefore out of bounds to Wyatt. ${ }^{16}$ In the royal forests, deer were the king's exclusive property, and many minor aristocrats owned a park, where they alone had the right to hunt. More than other animals, deer were therefore associated with the aristocracy, and hunting them with transgression. ${ }^{17}$ Dekker's audience may also have remembered another play associating deer stealing with attempted adultery: one or two years before the Shoemaker's Holiday, Falstaff

\footnotetext{
${ }^{14}$ Mortenson describes Hammon's pursuit of Rose as "poaching on Lacy's love territory" (1976:250).

15 On Hammon's reliance on the power of money, cf. Mortenson (1976:250) and Straznicky (1996:363).

${ }^{16}$ See Greenblatt (1980:145-150) for a detailed discussion of the poem's relation to Boleyn, which he sees as "plausible" though deliberately kept vague; and to Petrarch's original.

${ }^{17}$ For the political implications of the deer hunt, see Wilson (1992) and McRae (1996:260-261).
} 
had figured as the poacher, of deer as of married women, in Shakespeare's urban comedy, The Merry Wives of Windsor. ${ }^{18}$

Dekker's play, then, uses a misleading setting for the earliest phases of its love plot: the semi-pastoral countryside around London, which ought to be a place of innocence, is in fact where some of the play's transgressions take place: not just deceit, but also poaching and illicit wooing, the former being a metaphor for the latter. Nor is it Hammon and Warner only who engage in such transgressive exploits: Hammon's complaint to Rose, "I chased the deer; but this dear chaseth me" (6.33) proves truer than he knows, for Rose is not the passive female who simply waits for her lovers to come for her. Her father's complaint that Rose "loves [Lacy] so well|That I mislike her boldness in the chase" (1.7-8; italics mine) turns out to be partly justified by the plot. In the next scene, she dispatches Sybil to London to learn whatever she can about her lover; when she first meets Lacy alone, she urges him not to waste time but make arrangements for their marriage instantly, and within minutes decides to elope with him that very moment - a transgression that, in the end, only the king's pardon will make up for $(15.6-8 ; 15.50-51) .{ }^{19}$ Fittingly, Lacy urges Rose to hurry to the church: "Come, my sweet Rose, faster than deer we'll run" (17. 35; italics mine).

If the countryside, then, is no place of innocence or of free choice in love, neither is it the place of traditional hospitality. Here the usual roles of countryside and city are reversed. Sir Roger Oatley does seem to realise what social obligations come with having a house in the countryside, for as the Earl of Lincoln remarks, "you have sundry times $\mid$ Feasted myself and many courtiers more" (1.1-2). We are not told where these feasts took place, but Oatley invites Simon Eyre, upon the latter's appointment as Sheriff of London, "to dinner to Old Ford" (10.152). Eyre takes his journeymen shoemakers along with him, to provide music and morris dancing. The party, however, seems to lack true generosity: when Oatley apologizes for

\footnotetext{
${ }^{18}$ Smallwood and Wells note a resemblance between Simon Eyre and Shakespeare's Host of the Garter (Dekker 1979:17), but admit that the dating of Merry Wives, and therefore the direction of the influence, is uncertain (Dekker 1979:66-67n).

19 Smith also comments on Rose's eagerness and active role in the courtship (2005:343).
} 
the "bad cheer," Eyre politely denies this, but finds little to praise apart from the splendid surroundings: "Good cheer, my Lord Mayor, fine cheer; a fine house, fine walls, all fine and neat" (11.3-5). The common shoemakers, too, seem to have mixed feelings about their entertainment at Old Ford, though their language is somewhat cryptic to the modern ear, and not usually glossed satisfactorily. ${ }^{20}$ As I read it, the dancing - which they themselves brought to the feast was fun, but the food was disappointing:

HODGE: How sayest thou, Firk? Were we not merry at Old Ford?

FIRK: How, merry? Why, our buttocks went jiggy-joggy like a quagmire. Well, Sir Roger Oatmeal, if I thought all meal of that nature, I would eat nothing but bag-puddings.

RALPH: Of all good fortunes, my fellow Hans had the best.

FIRK: 'Tis true, because Mistress Rose drank to him. (13.29-34)

Hans, then, that is Lacy in disguise as a Dutch shoemaker, has had great fun, but only because Mistress Rose drank to him, rather than because of his own drinking. When Sybil, the maidservant at Old Ford, enters, Ralph politely thanks her: "Godamercy, Sybil, for our good cheer at Old Ford," but she replies, "That [the thanks?] you shall have, Ralph" (13.45-46) - a cryptic phrase that might be taken to suggest that the shoemakers are to be thanked for their music and morris dancing, and that it was this that provided the good cheer rather than the food and drink. ${ }^{21}$

The counterpoint to this apparently disappointing feast in the countryside, of course, is the lavish meal for all apprentices that Simon Eyre organizes at the play's end to celebrate his election as

\footnotetext{
${ }^{20}$ Parr speaks of the "hollow rituals of Oatley's regime" being "replac[ed] [...] with a genuine revels" - but does not really explain this (Dekker 1990:xxi). Smallwood and Wells comment on Oatley's "meanness", and remark that "the 'bad cheer' the Lord Mayor self-effacingly, and depressingly, offers is miraculously transformed by the operation of Eyre's language: 'Good cheer' [...]" (Dekker 1979:37). They do, however, suggest that, in his apostrophe to "Sir Roger Oatmeal," "Firk is reminiscing nostalgically about the high quality of the food (meal) and drink at Old Ford" (Dekker 1979:157n).

${ }^{21}$ Smallwood and Wells gloss: "Perhaps sarcastic; as a servant, she takes a jaundiced view of the entertainment the household would provide [...]" (Dekker 1979:158n). In their introduction, they remark that, in the feast at Old Ford, "The good cheer of the occasion $[\ldots]$ is all supplied by the guests, who bring the music, and the dancing $[\ldots]$ " (41).
} 
Lord Mayor. Even the king himself comes to visit, and completes the picture of social harmony by agreeing to partake in the meal. This feast has rightly been seen as a pastoral element, bringing the traditional values of the countryside to the heart of the City; and compared, in this respect, to Ben Jonson's Jacobean poem, "To Penshurst," which celebrates the country estate of the Sidneys in terms of the social, moral, and spiritual values that emanate from it, rather than the empty show so characteristic of other country houses, which have been infected by city values. Chief among the traditional country values is the hospitality that extends to all social layers, from the country clown by way of the middle class speaker himself to the king and his son: the dining table thus becomes an emblem of an organic society, where there is a place for everyone, from high to low. This applies to Simon Eyre's feast, too, suggesting that he has, indeed, emulated the values traditionally associated with the countryside and brought them into the heart of the City. No less striking, of course, are the differences: Eyre, unlike Sidney, is a commoner, who is not expected to provide such a feast, let alone hobnob with the nobility and even royalty. But he does behave nobly: his repeated catch phrase, "Prince am I none, yet am I nobly/princely born," suggests a deserved pride in his trade. ${ }^{22}$ Among the dishes served up at this feast for the commoners, we are told, are "venison pasties" (18.195), more usually associated with aristocratic entertainments. ${ }^{23}$

In these ways Dekker's Shoemaker's Holiday partly inverts, partly nuances, the clichéd expectations of certain spaces: Old Ford is not the pastoral idyll it may appear to be at first, but a place where a daughter is restrained against her will; but her father's expectations that isolating his daughter thus will keep her innocent are not fulfilled, as the enclosed garden turns out to be eminently permeable to deer, hunters, seducers, and lovers. From the father's perspective, the dangers associated with the City are no less present in the countryside, for his daughter is as rebellious and subtle at evading his control there as in London. Nor is Old Ford the site of

\footnotetext{
${ }^{22}$ Cf. Seaver: "And what is the audience to make of Eyre's repeated reference to 'the gentle craft,' the 'gentle trade,' and 'gentlemen shoemakers,' if not an assertion of a new gentility to be gained not by birth but by honest labour?" (1995:100).

${ }^{23}$ See Seaver (1995:97) for the nobility, by mouth of Lord Burleigh, taking offence at the consumption of venison at guild feasts - in a different context.
} 
countryside cheer and hospitality; if anywhere, it is in the City under Simon Eyre's mayoralty that this is to be found.

As we saw earlier, Jean Howard has argued that City Comedies suggest that the values of the suburbs have long since infected the City proper, so that binaries have become meaningless. In an analogous manner, The Shoemaker's Holiday has a levelling effect, in showing that the initial contrast between the pastoral countryside setting at Old Ford and the City of ambition and subterfuge is less strict than one expects. What the play leaves open is whether this is true for all such binaries, or just for Old Ford in particular, as a village not far from London: all we see of the village is the household of Sir Roger, whose own background as a grocer suggests that he, too, like Simon Eyre, acquired his wealth and title through a City career. Like those nouveaux riches who, in Jonson's "To Penshurst," have lately built their proud ambitious mansions in the countryside, Sir Roger is not a real country gentleman but a City man who has brought his City values to Old Ford. In this respect I disagree with Hayes, who sees "the city not as threatening that rural ideology, but rather as participating in it" (2000:28). On the contrary, city and country influence each other, as people move from one to the other, bringing their old habits with them. In a different context, McRae speaks of "the power of the city [which] is seen to sprawl uncontrollably outward into the countryside" (1996:100). As Seaver has found, some months before the play was first staged some hundreds of apprentices from London had "gathered in the summer evenings 'under colour of going to a place called the Old Ford to bathe themselves,"' and rioted there and on the way (1995:91). Seaver concludes that Dekker "transforms this locus of youthful rioting to the scene of a romantic pastoral" (1995:91-92). In my view, however, Old Ford is represented less as a pastoral idyll than as a place in the countryside where Londoners have come to live and recreate themselves, taking their city values and habits with them: ${ }^{24}$ the mirror image, therefore, of Simon Eyre bringing the pastoral concepts of generosity, social coherence and the dignity of work into

\footnotetext{
${ }^{24}$ Hayes (2000) stresses the influence of country gentlemen who come up to London to be corrupted there. In Dekker's play, however, Oatley, Rose, Sybil, and Hammon are city dwellers who, for various reasons, have come to Old Ford. As the household of Sir Roger is all we see of Old Ford, we do not know what the "real" villagers are like.
} 
(3) ederi 22 (2012)

the City. London and the surrounding countryside cannot help influencing each other, which exerts a levelling effect blurring all binaries, in real life as in Dekker's fiction.

\section{References}

Chaudhuri, Sukanta 1989. Renaissance Pastoral and its English Developments. Oxford: Clarendon Press.

Dekker, Thomas 1979 (1599). The Shoemaker's Holiday. The Revels Plays. Ed. R. L. Smallwood and Stanley Wells. Manchester: Manchester University Press.

Dekker, Thomas 1990 (1599; 1975). The Shoemaker's Holiday. New Mermaids. Ed. Anthony Parr. London: A \& C Black.

Greenblatt, Stephen 1980. Renaissance Self-Fashioning from More to Shakespeare. Chicago and London: The University of Chicago Press.

Hayes, Carol 2000. "Mapping City Comedy Topographies of London and the Anomalous Woman, 1599-1625." Diss. University of California, Irvine.

Howard, Jean E. 2007. Theater of a City: The Places of London Comedy, 15981642. Philadelphia: University of Pennsylvania Press.

Li, Chi-Fang Sophia 2009. Review of The Shoemaker's Holiday at the Rose Theatre London, November 2008. Shakespeare Bulletin 27/3: 146-150.

Maddocks, Sydney 1933. "Old Ford." The Copartnership Herald 3/31. <url: www.mernick.org.uk/thhol/oldford.html>. Last accessed 22/08/2011.

Manheim, Michael 1970. "The Construction of The Shoemaker's Holiday." Studies in English Literature, 1500-1900 10/2: 315-323.

McRae, Andrew 1996. God Speed the Plough: The Representation of Agrarian England, 1500-1660. Cambridge: Cambridge University Press.

Mullaney, Steven 1982. The Place of the Stage: License, Play, and Power in Renaissance England. PhD Thesis. Stanford University. Ann Arbor: University Microfilms International. (Later published as a book: Chicago-London: University of Chicago Press, 1988).

Mortenson, Peter 1976. "The Economics of Joy in The Shoemakers' Holiday." Studies in English Literature, 1500-1900 16/2: 241-252.

Nicholl, Charles 2007. The Lodger: Shakespeare on Silver Street. London: Penguin.

Scott Kastan, David 1987. "Workshop and/as Playhouse: Comedy and Commerce in The Shoemaker's Holiday." Studies in Philology 84/3: 324-337. 
Seaver, Paul S. 1995. “Thomas Dekker's The Shoemaker's Holiday: The Artisanal World." Eds. David L. Smith, Richard Strier and David Bevington. The Theatrical City: Culture, Theatre and Politics in London, 15761649. Cambridge: Cambridge University Press: 87-100.

Smith, Amy L. 2005. "Performing Cross-Class Clandestine Marriage in The Shoemaker's Holiday." Studies in English Literature, 1500-1900 45/2: 333355 .

Straznicky, Marta 1996. "The End(s) of Discord in The Shoemaker's Holiday." Studies in English Literature, 1500-1900 36/2: 357-372.

Twyning, John 1998. London Dispossessed: Literature and Social Space in the Early Modern City. Houndmills, Basingstoke: Macmillan Press.

Williams, Raymond 1973. The Country and the City. London: Chatto and Windus.

Wilson, Richard 1992. "'Like the Old Robin Hood': As You Like It and the Enclosure Riots." Shakespeare Quarterly 43/1: 1-19.

How to cite this note:

Paul J. C. M. Franssen. "Sites of transgression: The suburbs and the city in Thomas Dekker's Shoemaker's Holiday." SEDERI 22 (2012): 139-154.

Author's contact: P.J.C.M.Franssen@uu.nl

Submission: 10/02/2012

Acceptance: 11/04/2012 